\title{
BEYOND THE INTER-NATIONAL RELATIONS FRAMEWORK: An Essay In Descriptive Global Ethics ${ }^{i}$
}

\author{
Des Gasper \\ Post-print of an invited paper that appeared in the inaugural issue of the Journal of \\ Global Ethics, 1(1), 5-23
}

\begin{abstract}
Discussions of global ethics - about the types of normative claim made on individuals and groups, not only states, by individuals and groups around the world-have had to move beyond the categories inherited in the International Relations discipline. Many important positions are not captured by a framework developed for discussion of inter-state relations. The blindspots seem to reflect an outmoded expectation that (i) giving low normative weight to national boundaries correlates strongly with (ii) giving more normative weight to people beyond one's national boundaries, and vice versa; in other words that these two dimensions in practice reduce to one. The paper develops an enriched categorization. We need to recognize the separate importance of the two dimensions, and thus distinguish various types of 'cosmopolitan' position, including many varieties of libertarian position which give neither national boundaries nor pan-human obligations much (if any) importance.
\end{abstract}




\section{INTRODUCTION}

Global or world ethics is the study of ethical claims made on human beingsindividually or in groups, not only grouped as states - in their relations with individuals and groups (again not only states) throughout the world (Dower, 1998). ${ }^{\text {ii }}$ Authors such as Nigel Dower and David Held have examined the broadening of attention beyond states, in the context of the intensification of global interconnections and internationalizing of problems of absolute poverty, conflict, environment, refugees and more. ${ }^{\mathrm{iii}}$

For pursuing the global ethics agenda, this paper argues for wide-ranging description and analysis of existing ethics, including practices as well as doctrines, and not only the elaboration, evaluation and advocacy of old or new formal doctrines. Section I suggests the importance of this sort of sociology of ideas and practices, by reference to the growth of groups and persons who have attenuated or no national loyalties and instead worldwide but not pan-human loyalties, and to assumptions yet that nations form communities bound by a social contract.

Attention to a wider range of actors, and to practices as well as doctrines, leads the study of global ethics beyond traditional normative International Relations with its focus on the relations between states. The common expectation has been that positions which stress the normative importance of national boundaries will also put low weight on obligations that cross national boundaries, in particular obligations on the basis of a common humanity; and vice versa, that low normative weight to national boundaries will go with higher weight to global obligations. We will see that the expectation is misleading, and that a wider range of positions must be investigated, including positions which give neither national boundaries nor pan-human global obligations much (or sometimes, any) importance. Section II essays an extended taxonomy of standpoints in global ethics.

Section III takes further the identification and clarification of these 'neither-nor' positions. They include enormously influential anti-humanist stances, notably for unrestricted markets and even for unrestricted contestation as the principle for all spheres of life. We will specify various such positions: in current responses to crises in the supply of global public goods; in the reconsideration and decline of international aid in the 1980s and 90s; and in the Darwinian 'ethics' of those who will trade in anything.

Section IV offers a set of conclusions and underlines the importance of descriptive ethics for any realistic and effective practical ethics.

\section{FROM SOCIAL CONTRACT TO MARKET CONTRACT}

Namibia is an unusual country with a painful history. It has had at one stage possibly the highest Gini coefficient for income inequality in the world. Its large groups of white settlers, both German and Afrikaner, enjoy exceptionally high average incomes, in what has been otherwise very largely a country of poor people. This is a country with manifestly no integrated national community. Many white Namibians seem like a continuing colonial group or as in effect long-term expatriates who require-in other words demand - almost the same rewards as short-term expatriates plus greater rights and opportunities than them, and who are likely to emigrate when they no longer receive these. An extreme and minor case, surely? 
Let us turn to a country with almost a sixth of the world's population: India. If one walks the streets of a metropolis in India nowadays one can sometimes get a feeling that not only the rich but also increasing numbers of the professional classes have morally seceded from the nation (cf. Bhaduri \& Nayyar 1996). Many seem to live now the same in various ways as do Indian professional emigrants abroad, or foreign tourists, or those same tourists when back home in the North. The smartly dressed wellto-do proceed from gleaming cool office or home interiors, communicating to each other on their cell phones, through streets with many wretched begging people whom they generally ignore, to shops and hotels full of luxuries and imports from America, Britain and Singapore for which they can evidently afford to pay world prices. In the 1990s while consumerism reached new levels in India, public social sector expenditures were squeezed. The affluent seem to have become semi-detached in their own country, inhabitants of a quasi-apartheid system moving further in the direction of Brazil or South Africa. In effect they declare that if the elites and middle classes of other parts of the globe are entitled to live in a certain way, then so are they - by the principle of equal real income (post-taxation) for equal work.

What's new? Was it ever different? Consider masses of Indians starving in the 1870s and 1890s in the interior, or in the streets of Calcutta in 1943 while grain was procured for war purposes; or the Irish expiring en masse in the 1840s while grain was exported and the society balls rolled on in Dublin and London. The ruling and professional classes of those periods were often international too, with investments and family members spread across the world. But after India's independence in 1947 drastic mass starvation has been prevented by timely public action. And while the failures to attend in non-starvation times to the basic needs of up to half the population-and the concomitant evasion of taxation-were a national and global scandal (Harriss-White \& Subramaniam, 1999), the national community appeared as a dominant image and aspiration. External criticism was sometimes resisted precisely on those grounds: 'You cannot criticize or share in policy discussions about India if you are not a resident national, sharing these conditions, this destiny, its joys and pains'-a principle of, if not equal pay for equal work, then at least equal voice only if equal pay. ${ }^{\text {iv }}$

At least three shifts may have happened, in significant measure, in the past generation.

- The ethics have been globalized and liberalized: elites may comment on anything, worldwide, but have been liberated from obligation. The principle espoused by many has become: "If we are obligated to the poor here in India [no longer 'our poor'], then so are you. Since you are not, then nor are we."

- Professional and business elites in the South can now emigrate mentally rather than physically, thanks to the intensity of trans-national communication and flows. The software engineer in Bangalore, Chennai (Madras), Hyderabad or Pune employed directly or indirectly by a corporation in Europe or America can now live in many ways almost the life of his emigrated classmate in the North.

- The vastly eased and intensified transnational contacts and flows - messages, visits, financial transfers - allow even an average professional family of the new millennium to act as a global unit. What made the Rothschilds special and supreme in the early and mid 19th century is now mundane.

My main point is however not historical, not dependent on whether or not this sort of stance is new or has grown; rather that such positions are widespread and significant. India was already a country where group and family loyalties took precedence, where 
condensation into a national entity was quite limited. Great numbers still emigrate physically - a high proportion of the best Indian engineers, computer specialists, doctors, and scientists of every description: sometimes even the majority of the output of elite training institutions heavily supported with public funds as a subsidy to elite and upper middle class families. Once abroad many remain in some ways mentally in India: in an émigré cocoon, and intensively connected home through telephones, e-mail and chatrooms, money transfers, visits in both directions, etcetera. Many do return. Whether they return home, and stay home, may make little difference to their loyalties: their life-norms are often largely the same as the émigrés. They commonly want to work for the same corporations, acquire, consume, travel and perhaps invest abroad, send their children there for studies and work. Often the extended families function as multi-national corporations: they are the project, more important as a machinery, base of identity and focus of investment than the nation. The nation is one base for their activities, but not predominant organizationally, let alone normatively.

Many authors continue to assume that there are national social contracts, and that the condensation into national entities and largely territorially (rather than functionally) based governance which occurred gradually between the $16^{\text {th }}$ and $20^{\text {th }}$ centuries remains dominant. $^{\mathrm{v}}$

A responsible national government speaks for all the people in its country; as such, it has the duty to protect its vulnerable citizens from the harmful effects of free markets while taking advantage of the benefits they offer. ... a responsible national government has the duty to protect weaker portions of society from stronger portions... (McKeever, 2000-2001; final essay).

'A responsible national government' is assumed by McKeever to be responsible to 1 . 'all the people in its country'; not to 2. 'the country' as measured by financial wealth, nor to 3. all people in the world. The proposal to protect weaker sections may rely on the existence of a feeling of national community. McKeever presents a quasicommunitarian model in which producers in rich Northern countries (say, farmers) should be protected against international competition, by governments which represent and sustain national communities. These governments will not represent also the interests of outsiders. Insofar as such interests are reflected through effective demand in the market, and hence financial rewards for some nationals, the governments are supposed to control markets rather than be controlled by them, and to represent all nationals, not only those who receive market rewards.

Thomas Nagel uses a partly similar model in his reflections on 'The Problem of Global Justice' (2005). He presumes that there exist national 'societies', whose internal relations should be governed in ways that inevitably remain radically different from 'the practices that govern our relations with individuals in other societies' (p.118: emphasis added). From Hobbes' thesis that the operations of justice rely on the presence of a sovereign power, Nagel projects that the very notion of justice is inapplicable to contexts which lack a sovereign power, namely to relations with members of 'other societies'.

Onora O'Neill's remarks on communitarianism may have a wider relevance:

The upsurge of communitarian thinking [in the North] about virtue and (in small measure) about justice in the 1980s fits oddly with the reality that economic and political structures were and are becoming increasingly cosmopolitan. Might it reflect the fact that cosmopolitan claims are no longer advantageous to [Northern] elites, as they perhaps were or were thought to be in the recently past era of imperialism? In a post-imperial world, cosmopoli- 
tan arrangements threaten rich states with uncontrolled economic forces and immigration and demands for aid for the poor of the world, and autocratic states with demands that human rights be guaranteed across boundaries. (O’Neill, 1996: 28-9)

David Held derives a different picture than Nagel, from much more extensive, concrete consideration of diverse modern-day global interconnections: we exist in not a system of block-like nation-states - not even the United States is such a block - but a world system of innumerable overlapping communities. And as in Toni Erskine's 'embedded cosmopolitanism', an inclusive ethic can arise because individuals are simultaneously members of many, overlapping, non-territorial, morally constitutive communities. 'The ideal number of appropriate democratic jurisdictions cannot be assumed to be embraced by just one level' (Held 2004: 102).

With these introductory examples in mind, let us try to build a picture of the range of viewpoints in global ethics.

\section{POSITIONS IN GLOBAL ETHICS: BROADENING OUR VIEW}

\section{Dower's classification}

Nigel Dower's exemplarily clear World Ethics - The New Agenda (1998) characterizes and assesses three normative approaches to international relations and compares how they treat a series of broad problem fields.

1. First, 'sceptical realism'/ 'international scepticism' holds that countries (nation states / national States / ...) overwhelmingly do and should pursue their own (longterm) interests, even when that involves breaking agreements.

2. Second, 'internationalism' and communitarianism hold that, while countries are the primary units on the world stage, held together internally as established communities, a community of countries emerges to some degree, for and through regulation of their interaction and mutual continuation. Within that community a modus viven$d i$ is established, with agreements which must be respected, just as within countries. The participants (the national States) remain predominantly ethical nationalists, so that the label 'inter-nationalism' fits this case better. ${ }^{\mathrm{vi}}$

3. Third come cosmopolitan positions, which hold that all humanity is the reference group in ethical discussions, some common values apply across humanity, and some responsibilities exist towards all humanity. ${ }^{\text {vii }}$ Three major variants are presented:

- 'libertarian-minimalism' [Cosmopolitan 1], in which individuals and their liberties are all that matter worldwide, not nations/States, which must not interfere with those liberties;

- 'idealism-dogmatism' [Cosmopolitan 2], in which some more extensive set of values is deemed globally appropriate and to be promoted; 'solidarist-globalist' would be a more descriptive, less evaluative, label for this position;

- 'solidarism-pluralism' [Cosmopolitan 3], in which global-wide concerns and obligations are emphasized but with large spaces accepted for variation in values and behaviour between settings. Dower adopts this position, and tries to delink valid points in communitarianism from its relativist and sectarian variants. 
Thus Dower discusses five approaches in all. The classification goes further than many previous treatments. We will see how it still needs to be extended.

Of the positions we looked at, McKeever's would most fit communitarianism. In contrast, the positions of some Indian emigres, whether mental or physical emigres, might approximate most to 'libertarian-minimalism', and lead us to distinguish two dimensions: the ethical status accorded to national boundaries, and the acceptance or not of pan-human obligations as opposed to obligations arising out of specific contracts or affinities.

Using these two dimensions, Dower's five approaches can be compared and ordered as in Figure 1. This suggests how diverse is Dower's 'cosmopolitan' family: it fills three of the four cells. Positions which meet either of the two criteria- low weight placed on national boundaries, and acceptance of global-wide values and responsibilities-seem accepted as cosmopolitan, yet the two criteria are very different. One is the cosmopolitanism of free trade areas, the other that of priority to basic needs worldwide. Let us examine this further.

\begin{tabular}{|c|c|c|c|}
\hline \multirow{2}{*}{\multicolumn{2}{|c|}{$\begin{array}{l}\text { Figure 1: An analysis of Dower's } \\
\text { five-fold classification of } \\
\text { approaches }\end{array}$}} & \multicolumn{2}{|c|}{ PAN-HUMAN VALUES \& RESPONSIBILITIES ? } \\
\hline & & $H I G H$ & $L O W$ \\
\hline \multirow{2}{*}{$\begin{array}{l}\text { ARE NATIONAL } \\
\text { BOUNDARIES } \\
\text { ETHICALLY } \\
\text { IMPORTANT? }\end{array}$} & IMPORTANT & $\begin{array}{l}\text { 'Solidarist-pluralist' } \\
\text { (= Cosmopolitan 3) }\end{array}$ & $\begin{array}{l}\text { 'International sceptic'; } \\
\text { 'Inter-nationalist'; } \\
\text { Communitarian }\end{array}$ \\
\hline & $\begin{array}{c}\text { NOT } \\
\text { IMPORTANT }\end{array}$ & $\begin{array}{l}\text { Full cosmopolitans } \\
\text { ('idealist-dogmatist'/ } \\
\text { 'solidarist-globalist'; } \\
\text { = Cosmopolitan 2) }\end{array}$ & $\begin{array}{l}\text { 'Libertarian-minimalist', e.g. } \\
\text { TNCs without national loyalties } \\
\text { (= Cosmopolitan } 1)\end{array}$ \\
\hline
\end{tabular}

\section{Investigating and broadening the classification}

Dower's classification and discussion seems to reflect still an International Relations (IR) tradition. International scepticism and inter-nationalism are views standard and central in the IR discipline. Dower's purpose is to recognize the range of starting points and then seek areas of agreement where different views can reach a common conclusion even if by different routes. A declared solidarist-pluralist cosmopolitan, his own views thoughtfully mix elements drawn from the strengths of various philosophical traditions, with an emphasis on priority to fulfilment of common basic needs, as rationally required for the coherence of each tradition (including libertarianism). He concludes against strong versions of solidarist-globalism: 'World government would only be acceptable when it would become unnecessary. So let us be good world citizens instead' (1998: 196). World citizen here means member of a global political community that is far less integrated than a state.

The IR-based classification needs to be elaborated. There are fewer differences in practice between 'sceptical realists' and 'inter-nationalists' than exist within the cosmopolitan category. Dower's sceptics about inter-national morality manage to not also be sceptics about intra-national morality and duties; they can even be communitarians intra-nationally. And while the libertarian-minimalists indeed give no priority to national boundaries but rather to personal boundaries - they deny having large responsibilities to almost any others, not only to foreigners - as a result they may be far closer on many international issues to the sceptics and nationalists than to other cosmopolitans. Dower's statements about cosmopolitan views do not always hold for 
libertarians who deny human solidarity and extensive obligations to others. ${ }^{\text {viii }}$ Further, some libertarians, zealots for unrestricted world markets, well fit Dower's label 'idealist-dogmatist cosmopolitan' even though not the content he attaches to the label. It seems better to distinguish that content by the separate label 'solidarist-globalist'.

We need then not only two dimensions of classification-whether values and responsibilities of global scope are accepted or not; and whether or not national boundaries are considered important - to adequately grasp Dower's five positions. We have to at least specify strong, intermediate and anti- views on each axis. We thereby identify four more positions, which Figure 2 below marks in italics.

\begin{tabular}{|c|c|c|c|c|}
\hline \multirow{2}{*}{\multicolumn{2}{|c|}{$\begin{array}{l}\text { Figure 2: A fuller classification } \\
\text { of viewpoints in global ethics }\end{array}$}} & \multicolumn{3}{|c|}{ PAN-HUMAN VALUES \& RESPONSIBILITIES ? } \\
\hline & & EXTENSIVE & MODEST / SLIGHT & NONE \\
\hline \multirow{3}{*}{$\begin{array}{l}\text { ARE } \\
\text { NATIONAL } \\
\text { BOUNDARIES } \\
\text { ETHICALLY } \\
\text { IMPORTANT? }\end{array}$} & $\begin{array}{l}\text { VERY } \\
\text { IMPORTANT }\end{array}$ & 1. 'Scandinavian' & 2. 'Inter-nationalist' & $\begin{array}{l}\text { 3. 'International } \\
\text { sceptic' }\end{array}$ \\
\hline & $\begin{array}{l}\text { INTERMEDIATE } \\
\text { IMPORTANCE }\end{array}$ & $\begin{array}{l}\text { 4. 'Solidarist- } \\
\text { pluralist' } \\
\text { [Cosmopolitan 3] }\end{array}$ & $\begin{array}{l}\text { 5. TNCs with national } \\
\text { loyalties/priorities but } \\
\text { some accepted global } \\
\text { duties }\end{array}$ & $\begin{array}{l}\text { 6. Typical } \\
\text { domestic } \\
\text { corporation }\end{array}$ \\
\hline & $\begin{array}{l}\text { NOT } \\
\text { IMPORTANT }\end{array}$ & $\begin{array}{l}\text { 7. Full cosmopol- } \\
\text { itans (solidarist- } \\
\text { globalist) } \\
\text { [Cosmopolitan 2] }\end{array}$ & $\begin{array}{l}\text { 8. 'Libertarian- } \\
\text { minimalist', e.g. } \\
\text { TNCs without } \\
\text { national loyalties but } \\
\text { with some accepted } \\
\text { necessary global } \\
\text { duties ['Soros' - } \\
\text { Cosmopolitan 1] }\end{array}$ & $\begin{array}{l}\text { 9a) Business-only } \\
\text { corporations } \\
\text { 9b) Robber-baron } \\
\text { corporations } \\
\text { 9c) Family \& clan } \\
\text { 'corporations' } \\
\text { 9d) 'L'étranger' } \\
\text { individuals }\end{array}$ \\
\hline
\end{tabular}

Non-italicized positions $=$ discussed by Dower. Italicized positions $=$ not covered by Dower .

One of the four additions is perhaps typically Scandinavian (\#1), a combination of strongly felt global responsibilities and strongly felt national identity and loyalty. There is no inconsistency between giving priority to needs at home while still having major concern for needs abroad. Concern for others, grounded in sympathy, is unlikely to suddenly cease at the national border. Lack of concern for foreigners is perhaps the more likely partner for a lack of concern for 'fellow-citizens'.

There are disagreements on the minimum needed to maintain a libertarian system, and thus on the appropriate meaning of 'libertarian-minimalism'. Consistent with Dower's intentions, I here take it as the stance of a 'pure' transnational corporation (TNC), i.e. one without national loyalties, which yet actively seeks to sustain a system of global order (Position 8). It not only follows laws and agreements but is ready to invest in 'global services', perhaps also to maintain the credibility of an equalopportunity liberal ideology. ${ }^{\text {ix }}$ We could call it the Soros stance.

The other additions are possible business corporation viewpoints (\# 5, 6 and 9) which differ from the Soros stance. Position 5 includes corporations which retain a primary national loyalty but do invest a certain amount in good causes worldwide; for example Ford or various Japanese TNCs. Position 6 includes corporations which have only the primary national loyalty: they feel some concern to maintain community viability in their home base, not elsewhere, but even this can be outweighed by the call of profit. Position 9a includes corporations which have no such national loyalty, nor 
any geographically wider loyalties other than profit. In Position $9 b$ the concern for profit and disregard for national jurisdictions leads to disregard for national laws too: the 'robber-baron' capitalist is ready to buy officials and politicians, not only (other) commodities.

The 'neither-nor' category also includes the cases we saw earlier: individuals or groups estranged from national loyalties (9c and 9d). The individual could even be estranged from almost any human loyalties, like Camus's "L'Etranger", a European colonist who casually kills an Arab (barely recognized as such, or as human) in French Algeria. We will consider later how far these Darwinian positions, the robber-baron and l'étranger, deserve to be called global ethics. L'étranger as colonialist, or even immigrant, continues as a major player worldwide (as currently in some instances in Israel, Brazil, and other locations).

Clearly identifiable as an ethic with worldwide obligations are the values of the family, lineage or clan which is spread across two or more countries and operates to provide members with support. A hybrid case that deserves separate attention are the criminal mafias, which combine 'robber-baron' predation, 'family' bonds, disregard for national bounds, and routine killing. The positions in cell 9's neither-nor category might be called 'post-liberal'; but historically speaking they seem 'pre-liberal' too. The number of variants suggests that one might later further refine the classification dimensions and labels.

Figure 2 already suffices for some important findings. Note first the distribution of attention across the various viewpoints.

- Dower's IR-based classification (covering the non-italicized positions) is stronger in attention to the bottom-left to top-right diagonal in Figure 2. For it may have presumed correlation between positions in the two dimensions: that low ethical importance given to national boundaries will conduce to acceptance of values and responsibilities with global scope, and vice versa. That assumption appears outmoded (again). Positions along the top-left to bottom-right diagonal need major attention too.

- Since States consider national boundaries (very) important, IR discourse has concentrated on positions like 2, 3 and even 4, but with position 7 as an idealist counterpart or outpost which matches the same belief in a correlation.

- Positions in the bottom right of the diagram - position 8 and the family of positions in 9-may be growing. They hold that national boundaries are not ethically important, but that there are few or no responsibilities with global scope.

We can see secondly the value of multiple criteria in classification. Using two dimensions lets us tackle the ambiguity in the term 'cosmopolitan'. Even the five positions covered by Dower are hard to fit into a single low-to-high sequence (is \#8 more cosmopolitan than \#2, or vice versa ?). Cosmopolitanism in one respect (low weight to national boundaries) can be combined with extreme parochialism in the other (non-interest in foreigners). As we will explore in Section III of the paper, position 9 is thus more comprehensively sceptical than the 'international sceptic' position 3 . It rejects national loyalties as well as trans-national pan-human ones.

Thirdly we see the need for more than binary contrasts along the dimensions. The gaps only emerge to view when we introduce intermediate positions. These allow us to resolve the uncomfortable grouping together of inter-nationalists and international sceptics at the top-right in Figure 1. Comparable unpacking of the bottom-right of that table reveals leads us to distinguish some fundamentally different viewpoints. In fact 
we found it necessary to refine the categorization everywhere outside the full cosmopolitan bottom-left cell of Figure 1: both the row above that cell and the column to its right needed to be divided.

A similar concern arises when one reads Charles Gore's insightful picture of major positions and trends in development policy analysis (see Figure 3). The types of global ethic contained in his final column are very varied.

\begin{tabular}{|c|c|c|c|}
\hline \multirow{2}{*}{\multicolumn{2}{|c|}{$\begin{array}{c}\text { Figure 3: Gore on paradigms } \\
\text { in development policy } \\
\text { analysis } \\
\text { (Gore, 1996; Gore, 2000) }\end{array}$}} & \multicolumn{2}{|c|}{ NORMATIVE FRAMEWORK } \\
\hline & & National & Global \\
\hline \multirow{2}{*}{$\begin{array}{l}\text { EXPLANATORY } \\
\text { FRAMEWORK }\end{array}$} & National & $\begin{array}{l}\text { Competing mainstream } \\
\text { development paradigms pre- } \\
\text { 1982, e.g. balanced v. unbal- } \\
\text { anced growth }\end{array}$ & $\begin{array}{c}\text { 1. Dominant development } \\
\text { paradigm post-1982 (labelled as } \\
\text { 'Washington Consensus') } \\
\text { 2. 1990s Sustainable Human } \\
\text { Development }\end{array}$ \\
\hline & Global & $\begin{array}{l}\text { Counter-currents pre-1982 (Latin } \\
\text { American structuralism \& } \\
\text { dependency theory). } \\
\text { East Asian models. } \\
\text { Latin American neostructuralism }\end{array}$ & $\begin{array}{c}\text { Predicted paradigm shift in this } \\
\text { direction }\end{array}$ \\
\hline
\end{tabular}

If we use Dower's terms we might describe the 'Washington Consensus' as libertarian-minimalist. It is cosmopolitan in the sense that there is only one moral domain, but there are minimal (rather than zero) international obligations, just as there are minimal domestic obligations. UNDP's Sustainable Human Development School is closer to a 'solidarist-pluralist' stance or, in its variants which emphasise human rights (notably the 'human security' discourse), to 'solidarism-globalism' (Gasper 2005). It makes a great difference for Gore's predicted paradigm shift which of those cosmopolitan ethics will be the future 'global normative framework'. and also whether a shift into the bottom-right quadrant comes from the bottom-left or from the Washington Consensus. One fears the emergence of perspectives based on a sophisticated global framework for explanation and a consistently selfish, but global, normative framework. David Held's 'global compact' (2004) corresponds in contrast to the extension of the human development approach.

We could further elaborate the classification in Figure 2.

- One might change the definition of cosmopolitan so that it no longer spans two dimensions. One would then use 'cosmopolitan' (or 'universalist' or 'global') simply to mean acceptance of the world as in important respects one moral domain ('cosmos' as a 'polis') ${ }^{\mathrm{X}}$, across which members have some standard basic obligations and rights which should be respected for and by all; 's 'solidaristic' for views in which such obligations and rights are relatively extensive, as in the mainstream human rights perspective; and 'pluralistic' for respect for a plurality of ways of life and ethical conceptions. Robber barons can assert as universalists that the same values hold good everywhere, but be non-solidaristic in rejecting any extensive content to such values, any extensive obligations.

- With respect to the question 'values and responsibilities with global scope?', we might distinguish between three types of commitment: 1. pan-human, 2. worldwide but restricted to some types of person (e.g. from one's race or lineage or other network), 3. internal to the national political unit. 
- We might add other dimensions, for example concerning the level of agents being considered: state-corporation-ethne-clan/family-individual.

However, there will be no perfect classification and we have enough refinement already to have gained important insights. We have added an entire column at the right of the table, in which attention to pan-human reponsibilities is zero; and discerned a range of possible business viewpoints (positions 5, 6, 8, 9a to 9c, in Figure 2). Let us now apply the classification to debates on international aid and international economic relations. We will, in particular, examine the final, rejectionist, column -- especially the wellpopulated category 9, its 'neither-nor' hard core.

\section{III: ETHICS OF POSSESSIVE INDIVIDUALISM}

Through the 1980s and 1990s most Northern governments' aid budgets declined steadily as a proportion of national income and public expenditure. Per capita aid for Africans fell by $40 \%$ in the 1990s. The question 'Has international aid to poorer countries the right to exist at all?' was kept on the agenda through the 1960s and 1970s by a small number of Right-wing theorists antagonistic to aid, such as Peter Bauer, and became a major focus in the 1980s. ${ }^{\text {xii }}$ The following set of viewpoints indicates the spectrum. ${ }^{\text {xiii }}$

1. An obligation exists, the same as intra-nationally: International aid is seen as morally identical to resource transfers to poorer regions, groups or individuals within national boundaries (and domestic transfers are considered legitimate and desirable). Sometimes it is held that international aid should consequently be organised in a similar way to domestic transfers, routinised and with little space for discretion, as one part of welfare policy. But factual constraints differ in the international case and might profoundly affect and limit how and how far the rich can help.

This viewpoint matches the solidarist-globalist cosmopolitan category. Dower argues that solidarist-globalist and solidarist-pluralist positions are divided not on the degree of commitment to help, but on how we should help. One suspects though that solidarism-pluralism is liable in practice to give priority to domestic clients, for example by placing a heavier burden of proof on international aid.

2. Lesser obligation: Here, international aid is considered a moral obligation upon richer countries, groups and individuals, but subject to certain major conditions (for example concerning its urgency and expected efficacy; or about the existence of past and present North-South links), and is accorded in general lesser priority than obligations closer to home. This partly fits Scandinavia and the Netherlands, the donors who bind themselves to and implement a substantial target level of support; even if view 3, aid as charity, has influenced the manner in which they give.

Thomas Nagel approves of international aid to deal with life-threatening and life-reducing conditions, but wishes not to place rich countries in the same moral community as poor countries. He asserts that 'some form of humane assistance from the well-off to those in extremis is clearly called for quite apart from any demand of justice, if we are not simply ethical egoists' (2005: 118; emphasis added). Nagel calls it 'mere humanitarian assistance to those in desperate need' rather than 'Justice as ordinarily understood' (loc. cit.). In reality some others do not consider humanitarian assistance 'clearly called for', yet Nagel fails to argue for it other than by his 'If A then A' reference to ethical egoism. Even that reference fails: communitarians and others could be ethical altruists within their community yet reject the call to assist others 
outside 'it'. Nagel's failure to ground his support for humanitarian assistance in terms of a base-level human moral community-the claim made in doctrines of human rightsis matched by his failure to provide arguments on the other front too, against solidarist cosmopolitans, for why 'justice as ordinarily understood' is adequately understood. His conceptual schemas are artificial high-walled dichotomies, taken from an alleged 'ordinary understanding' that is deemed self-endorsing: the moral community is the nation-state, the arena for justice; justice is presented as a highly demanding notion, and so too therefore is cosmopolitanism, presented as the call for application of 'the full standards of justice', globally (p.142); and wider humankind forms a sort of animate environment for 'us', in relation to which 'we' should bear witness to our non-egoism but yet are not bound by requirements of justice. ${ }^{\text {xiv }}$

3. Charity: Here international aid is beyond obligation. To give it is an act of superogatory virtue and may be commendable. The work of development-oriented foundations such as Rockefeller and Ford, and Ted Turner's immense (albeit taxreducing) donation to the U.N., may reflect such a stance of benevolent charity. But not giving aid cannot be condemned. The former Soviet bloc, for example, held that it had no historical links with and hence no present obligations to give aid to the South.

4. My country first and only: aid to people in other countries is considered a betrayal of co-community members at 'home' who have unsatisfied needs and/or other claims - except when international aid furthers their interests better than would domestic uses. This position (e.g. Bauer, 1961) largely matches Dower's 'international sceptic' category. It influences some governmental aid, though not NGDO aid.

5. A matter solely for individuals to decide: Charity may be commendable, and national boundaries insignificant, but in this viewpoint individual self-ownership makes both intra- and inter-national obligatory (i.e. tax-derived) transfers immoral. The view that foreign transfers by a national government are illegitimate was long followed by Switzerland.$^{\mathrm{xv}}$ It is an implication of the influential possessive-individualist philosophy of Robert Nozick (1974), presented for consideration in development policy by Deepak Lal (1976). Tax-based aid provided by a donor government, and aid from corporate profits, are both deemed illegitimate, unlike voluntary trans-national aid from individuals. The position matches a 'business only' stance by a private corporation, and an 'international sceptic' position in a potential government donor.

6. Morally indifferent: whether a person or group of persons (e.g. an organisation) chooses to help others, either in their country or another, is here considered an entirely optional consumer matter. To do so is no better or worse than any other (legal) use of their wealth. Charity is not commendable. This position matches less humanistic variants in Figure 2's final column. A morally indifferent life-style option may be how most corporations view foreign aid (position 9a).

7. Culturally relative: here the 'consumer', the entity that adopts life-style options, is an entire culture. Some cultures are 'into' helping others, others are not, and, claims this viewpoint, there are no defensible ways of saying one value position is better than the other. This 'post-modern' stance differs from the nationalist viewpointwhich believes that its own position is better than others - but readily coexists with it. This position too matches Dower's communitarian category in part.

All of views 3 through 7 are widespread in the USA, including amongst powerful Republican politicians. A generation back, in the early days of the American New Right backlash, Sumberg (1973: 60) 'looked for...without finding [any] duty laid upon us. There is no such duty... [Aid] is purely discretionary', even in emergencies andaccording to him - even inside a nation. Typically in such views, attempted aid through 
governments is seen as pernicious: a channelling of rewards via the ignorant and corrupt to the incompetent and work-shy.

The US government (and corporate) position in discussions on climate change fits position 3, the 'international sceptic'. The US implicitly applies a market mentality in the discussions. Damage to others need not be culpable in a market framework, if not produced by direct assault or breach of a law. In fact the doctrine of competition demands that one try to inflict damage on competitors and indirectly on their employees and suppliers. After long denial of the damage, actual and impending, inflicted on others via environmental impacts of its high-gas lifestyle (twice the per capita greenhouse gas emissions of the European Union), damage that is no longer credibly deniable can instead be defined away. As with a corporation found to be polluting a common resource and hence indirectly damaging others, the defence may be offered that no one has property rights over the common resource. Therefore those who have broken no law and who only indirectly and unknowingly may have harmed others are, supposedly, non blame-able ('blame' originally means 'to speak ill of'). Within a defensive individualistic world-view, no blame means no responsibility for redress. ${ }^{\text {xvi }}$

The dispute over wider access to patented anti-AIDS drugs in the South, through low-cost supply from Southern companies, illustrates positions 6 and 9a, the stance of the business corporation, sometimes more charitably inclined in its home base. The patent-holding Northern pharmaceutical corporations sought for years to block access since they perceived it as at the cost of their profits and argued that the profits serve the long-run benefit of all by funding research. In reality such research is oriented towards the demands of those who can pay the most, not the needs in low-income countries. When one considers the scale of the health disaster and societal disaster in progress across much of Africa, its possible spillover effects, and the scale of the corporations' past and ongoing profits and dividends, such future profit projections appear shortsighted as well as obscene. But no exceptions were to be made - profit was rigorously defended: position 9a, business only. If an exception were made in this case, and needs put before projected profit, where would such argumentation stop? - nowhere short of dictatorship, has run the market mantra. Further, profit must be distributed to shareholders, and managers, otherwise a corporation risks being taken over. The corporations claim in addition the long run superiority for all of the market system. It seems unlikely that they would have maintained the same stance if the people dying were in the heart of Europe or America, rather than Africa; in that case position 6 (giving some weight to human needs within the corporation's country of origin) may become possible. In most of the North the gap between corporate profit needs and impoverished patients' life needs would also be substantially bridged by government action.

The $19^{\text {th }}$ century American poet Walt Whitman outlined a cosmopolitan vision:

One thought ever at the fore -

That in the Divine Ship, the World

breasting Time and Space,

All peoples of the globe together sail, sail the same voyage,

Are bound to the same destination.

(Whitman 1995: 497)

Whitman's vision is perhaps least shared in his own country, or only in a version in which America steers the ship towards the destination that she sets, and periodically 
disciplines passengers and junior crew, rather than a vision of global moral community. The ruling concept in America, when it extends to the outside world, is more how 'The new Rome meets the new barbarians', title for a 2002 piece by Joseph Nye, then dean of Harvard University's Kennedy School of Government and assistant secretary of defence in 1994-5. Writing in an international journal, the head of the leading American school of public affairs argued exclusively in terms of calculation of American national interest. Despite reference to requiring coalitions with others in order to defend American interests in areas like international financial stability, climate change, and the drugs trade, and notwithstanding awareness of the role of 'soft power', no generous word, no token of concern and esteem for other countries was used.

We can now consolidate certain key distinctions required within and beyond the 'libertarian-minimalist' category.

- Libertarian humanist positions. Some positions reject any distinction according to group or nation and declare respect for all individuals, who are to be as far as possible unconstrained, so far as consistent with equal freedom for others.

- Libertarian anti-humanist positions: legal market power. In practice, however, the most important operationalization of libertarian conceptions is through power in the market, and this leads in a dramatically different direction. Individuals are weighted in proportion to financial strength. Individuals without purchasing power are ignored. As we saw in the anti-AIDS drugs case, money-power's forms of cosmopolitanism and universalism are very different and anti-humanist, even though sometimes legitimized by use of libertarian humanist discourse. While these marketbased ethics formally centre on claims of providing fair process, their political viability may rest as much on the theology that market operation does in the long run benefit everyone, as compared to the benefits from the real alternatives.

- Libertarian anti-humanist positions: market power converted into lawless sociopolitical power and immunity. In principle, markets operate with respect for laws established at both national and, increasingly predominant, international levels. In practice, however some market operators systematically evade and subvert both national and international rules. 'Minimalism' applies for the proclaimed limits to their obligations, not for the scope of their own interventions.

For decades, traders from all over Europe have flocked to this lakeside Alpine town [Zug], attracted by stringent privacy laws, low tax rates and guarantees of corporate anonymity. But no one has achieved the dominance of Marc Rich, the billionaire metals dealer... [famous for] the business practices cited in his 1983 indictment for racketeering by the Southern District of New York -- trading with pariah states [e.g. as the leading supplier of oil to apartheid South Africa], manipulating the market for huge personal gain [e.g. cornering the international aluminium market in the early 1990s], hiding profits in a thicket of offshore companies.... While [Rich and his partner] denied wrongdoing and refused to produce documents relating to the [1983] case, they ended up paying \$200 million in back taxes and penalties in partial settlement...

"There is a lawless quality about the way he operates", Mr. Weinberg [prosecutor in the 1983 case] said. "He will do whatever he needs to do to close a deal."

"He sees himself as a citizen of the world, unencumbered by the laws of sovereign nations", said Howard Safir, a former U.S. marshal...

(International Herald Tribune, 14 March 2001; italics added)

Is this a global ethic? We would still need to consider Mr. Rich and his ilk even if it were not, as an analytically interesting and historically important outlier. Using Dower's definition though (cited at the start of this paper), Rich's "My Way" consti- 
tutes a system of ideas concerning the ethical obligations of human beings, individually or in groups, in their relations with individuals and groups throughout the world. But it would be an evolutionist ${ }^{\text {xvii }}$ or Nietzschean perfectionist ethic, in which unlimited contestation is claimed as the route to maximization of some excellence or prioritized qualities. ${ }^{\text {xviii }}$ It supports the extension of money power and market struggle to all matters: if one can buy aluminium, why not also voters, politicians, judges, legislators, regulators, even lives? The advocated rules apply universally and equally to all, to the strong and the weak. All are allowed to sleep under bridges, as Anatole France remarked; and the super-rich from anywhere are welcome in Zug.

\section{IV: CONCLUSION: the necessity of better descriptive ethics}

I have suggested the following points.

1. Global ethics as a field of study and practice needs to pay considerable attention not only to bodies of published prescriptive doctrine. It must examine intently the ethics implicit in practice.

2. It must in particular move beyond the state-centred perspectives and taxonomy of doctrines inherited from the academic field of International Relations; attend to agents other than the state; and not assume that views which accord low normative importance to national boundaries correlate strongly with views which grant high weight to the normative claims of people beyond those boundaries. Many national elites and other upwardly mobile groups seem de facto to reject both national and international moral community, except insofar as other people's claims are heard through market signals.

3. Normative IR and global ethics therefore must recognise and study positions which give neither national boundaries nor global pan-human obligations much ethical importance, the 'neither-nor' positions. These positions take individuals or groups as the relevant units, rather than nations, and do not revolve around debates advocating or denying duties between nations. It is not appropriate to group these views together as 'cosmopolitan' with other views which deny the moral priority of national boundaries.

4. Insofar as the label 'cosmopolitan' has ambigously spanned those two dimensions-(i) whether or not values and/or responsibilities of global scope are accepted; and (ii) whether or not national boundaries are considered normatively important - we could now reserve 'cosmopolitan' (or 'universalist') for acceptance of the world as in important respects one moral domain, across which members have some obligations and rights; and use 'solidaristic' for views in which such obligations and rights are relatively extensive.

5. Within dimension (i), we must further distinguish whether global commitments, if accepted, are: 1. pan-human or 2. worldwide but restricted to some types of person (e.g. from one's race or lineage). In the second case, the rejection of national moral community and pursuit of advancement on a global stage by many groups is often buttressed by the social capital and morality of their networks of kin and region, in some cases with their own functional equivalents of an international income tax. Communitarianism is alive and thriving at a global scale.

6. The 'neither-nor positions' seem to be relatively neglected in IR discourse. We noted: 9a) the business-only market agent, who pursues only profit but within the 
law; 9b) the 'robber-baron' market agent, who pursues only profit-period-and may use a Darwinian-Nietzschean perfectionist ethic; 9c): the 'family corporation', operating communally on a world scale; and 9d): the individual estranged from national and even active communal affiliations, perhaps pursuing some personal life-project while or by working for the global corporations and consuming their products.

7. Relatedly, 'libertarian-minimalist' ethics deserve closer attention and subdivision. (Table 2 distinguishes four relevant positions: 5, 6, 8 and 9a, not one.) The formal libertarian-minimalist ethics referred to in IR literature arguably do not cover the reality of business-only practice (Position 9a). As a body of doctrine a libertarianminimalist ethic is likely to present itself as strongly concerned with individuals and their freedom (e.g. Nozick, 1974) and thus with ensuring the necessary preconditions for such freedom (Position 8). In business-only practice, however, liberal doctrine becomes operationalized through market calculations which weight people by purchasing power and ignore those who have none. Our analysis of aid ethics showed further relevant divisions, notably concerning whether aid is seen as commendable even if not obligatory.

8. The relative analytic neglect of 'neither-nor' positions and some variants of libertarian thought are major substantive omissions for understanding the contemporary world. Market theology is strongly entrenched, as seen in the climate change discussions and in the long sustained attempts by drugs companies to have their familiar level of profit override the needs of AIDS sufferers. And the theology of Position 8 diverges from the usual actual practice of Position 9a, where only money talks in the market and big money has a megaphone; let alone from Position 9b, where all of life becomes a market. Amongst 'neither nationalist nor solidarist' positions, some are not humanist either.

9. We gain from a complex classification of views, with explicit dimensions of comparison and more than binary contrasts in each dimension. The main classification scheme used in this paper (Table 2 above) proved helpful, but we are straining at its limits and further refinement could be worthwhile. Applications are vital, however, to make the distinctions vivid, communicable, and demonstrably useful, and to deepen our awareness, before attempting much more taxonomy.

My main purpose has been descriptive rather than predictive or directly prescriptive: to provide better categories and ways of thinking about categorization, as a prelude to more detailed description. I have argued that the 'neither nationalist nor solidarist' positions, including anti-humanist variants, are massive, even central, in the modern world and are growing. They must be recognized and studied. Cohesive national communities, bound by social contracts within clear national containers, judiciously if sceptically pursuing some interpretation of their group interest in the world arena, cannot be presumed. More attention is needed to the constitution of the 'us', 'we', and 'self' in post-modern consumerism. We have to revise and extend our categories as we move from normative inter-national relations to global ethics. 


\section{References}

Bauer, Peter, 1961. Indian Economic Development. London: George Allen \& Unwin.

Bhaduri, Amit, \& Deepak Nayyar, 1996. Liberalization. New Delhi: Penguin India.

Caney, Simon. 2000. Cosmopolitan Justice and Cultural Diversity. Global Society, 14(4), 52551.

Dower, Nigel, 1998, World Ethics - The New Agenda, Edinburgh: Edinburgh University Press.

Erskine, Toni, 2000. Embedded Cosmopolitanism and the Case of War: Restraint, Discrimination and Overlapping Communities. Global Society, 14(4), 369-90.

Gasper, Des, 1986. Distribution and Development Ethics. In Development Studies - Critique and Renewal, edited by R. Apthorpe \& A. Krahl, Leiden: Brill, pp.136-203.

----, 1999. Ethics and the conduct of international development aid - charity and obligation, Forum for Development Studies (Oslo), 1999/1, 23-57.

----, 2005. Securing Humanity: Situating 'Human Security' as Concept and Discourse. Working Paper 405, The Hague: Institute of Social Studies.

Gore, Charles, 1996. Methodological Nationalism and the Misunderstanding of East Asian Industrialization. Pp.77-122 in Apthorpe, R., \& Gasper, D. (eds.): Arguing Development Policy: Frames and Discourses, London: Frank Cass (1996).

Gore, Charles, 2000. The Rise and Fall of the Washington Consensus as a Paradigm for Developing Countries. World Development, 28(5), 789-804.

Harriss-White, Barbara, \& Subramaniam, S. (eds., 1999), Illfare in India, Delhi: Sage.

Harrod, Jeffrey, 2001. The Global Retreat from Social Justice: Turning Point for Social Democracy? Valedictory Address, Institute of Social Studies, The Hague.

Held, David, 2004. Global Covenant. Cambridge: Polity Press.

Hurka, Thomas, 1993. Perfectionism. New York: Oxford University Press.

Korten, David, 1995. When Corporations Rule the World. London: Earthscan.

Lal, Deepak, 1976. Distribution and Development: A Review Article. World Development, 4(9), 725-38.

McKeever, Michael Pierce, Sr., 2000-2001. Essays on Moral Economics. Vista Community College, Berkeley, CA; URL: www.mkeever.com.

Nagel, Thomas, 2005. The Problem of Global Justice. Philosophy and Public Affairs, 33(2), 113-147.

Nozick, Robert, 1974. Anarchy, State and Utopia. New York: Basic Books.

Nye, Joseph, 2002, 'The new Rome meets the new barbarians', The Economist, 23 March, 2326.

O’Neill, Onora, 1996. Towards Justice and Virtue. C ambridge: Cambridge Univ. Press.

Opeskin, B., 1996. The Moral Foundations of Foreign Aid. World Development, 24(1), 21-44.

Pogge, Thomas, 2002. Moral Universalism and Global Economic Justice. Politics, Philosophy and Economics, 1(1), 29-58.

Riddell, Roger, 1987. Foreign Aid Reconsidered. London: James Currey.

Sumberg, T., 1973. Foreign Aid as Moral Obligation? Beverly Hills: Sage.

Whitman, W., 1995. The Complete Poems of Walt Whitman. Ware: Wordsworth Editions.

\footnotetext{
${ }^{\mathrm{i}}$ An extensively revised version of Working Paper 341, Institute of Social Studies, The Hague.

ii I will use 'global ethics' in preference to 'world ethics'. 'World' suggests world-level organizations, world-powers, etc., whereas 'global' suggests the sphere, across which numerous projects link and sum.

${ }^{\text {iii }}$ See Held (2004) for a readable survey.

iv See Gasper (1986), Section 7: 'Nationalist and Internationalist Ethics'.

${ }^{v}$ For powerfully argued other views, of the global business corporation as now dominant, see Korten (1995) and Harrod (2001).

${ }^{\text {vi }}$ The inter-national norms and agreements concern notably: respect for sovereignty; rules of warfare, rules of diplomacy, and the very principle of respecting agreements.

vii In Erskine's terminology, we refer here to 'ethical cosmopolitanism', not to world government.

viii Dower is not exceptional here. Caney for example presumes that 'No cosmopolitan argues for anything less than this [considerable international redistribution to alleviate poverty]' (2000: 526).
} 
ix The maverick billionaire George Soros has in fact a unique hybrid stance: he seeks to build national civil societies and effective polities, with the profits from his global financial speculation that undermines national economic sovereignty.

${ }^{x}$ According to the Penguin Dictionary of Philosophy, polites = citizen, and cosmopolitanism is the doctrine that we are citizens of a world.community.

xi Given now entrenched usages of 'cosmopolitan', 'universalist' may be the better label. Its referent in the text is consistent with Pogge's definition of moral universalism.

xii See Gasper (1986), Riddell (1987) and Opeskin (1996) for surveys of the debate.

xiii This section builds on Gasper (1999).

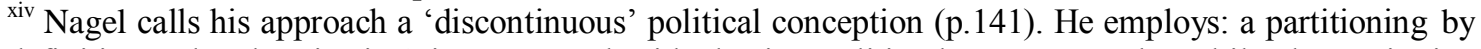
definition, whereby 'justice' is concerned with the inequalities between people, while 'humanitarian duties hold in virtue of the absolute rather than the relative level of need of the people we are in a position to help' (Nagel 2005: 119) -- as if justice does not arise in relation to matters of absolute need; and secondly, a maneuver by which 'The full standards of justice' (p.121) become the sole form of justice, via the notion of what 'merit[s] the full name of justice' (p.122). By p.140 he thus stipulates that 'Justice applies, in other words, only to...' what one might see as one, special, case thereof.

${ }^{x v}$ Switzerland is home too to the amoral or Darwinian Swiss banks and the genuinely charitable International Committee of the Red Cross, an international affairs committee with exclusively Swiss membership. 'International' in this label refers instead to the Darwinian mess in the world outside.

xvi On this world-view in the work of Hayek, see Gasper (1986), Section 5: Absolutization of Just Process.

xvii Inheritance of acquired characteristics is Lamarckean rather than Darwinian.

xviii In Rawls's sense, perfectionism in ethics holds that we should maximize excellence in art, science and culture (The Penguin Dictionary of Philosophy). Thomas Hurka defines it as promoting the expression and fulfilment of those features which are deemed to make humans human - e.g. for Aristotle rationality, for Marx productive activity, or for Nietzsche the exercise of the will to power (Hurka, 1993:3). He delineates Nietzsche's views as a form of perfectionism, including the principle of maximizing the quality of a minority of the best individuals. 